\title{
The Politics of LGBQTI Human Rights in the United Nations System
}

Dominic McGoldrick

Summary

Keywords: human rights, United Nations, international law, international institutions, sexual orientation, gender identity, culture, traditional values,

Introduction 
This article examines the development of LGBQTI human rights within the UN system. The focus is predominantly an institutional one, that is, on the major forums within the UN system where general human rights issues are discussed. The developments identified have taken place within a context of major political and legal disagreements between states. There has been a limited degree of recognition and acceptance. This is evidenced by reference to practice in the UN General Assembly and the UN Human Rights Council, Some of the impetus for this has come from the elements of the UN human rights system that are independent - the Treaty bodies and the Special Procedures. The crosscutting nature of human rights means that LGBQTI human rights are increasingly addressed across the whole range of UN human rights mechanisms. However, the political and legal contestations continue. They are partly framed within an anti-colonial critique, but also with respect to the protection of culture, traditional values and the family. Given the level of contestation, further progress at the UN on LGBQTI human rights is by no means inevitable. The politics of LGBQTI human rights in the UN system naturally reflects the divergences that are evident in the major regional systems. Normative developments in LGBQTI human rights in Europe and the Americas are significantly in advance of those in Africa and Asia (Ayoub, 2016; Baisley, 2016; McGoldrick, 2016). The European Court of Human Rights (Johnson, 2013; $\underline{\text { Sundstrom, Sperling and Sayoglu (2019) and the Inter-American Court of Human Rights }}$ (State Obligations Concerning Change of Name, Gender Identity, and Rights Derived from a Relationship Between Same-Sex Couples (Advisory Opinion, 2018) have strongly influenced, if not led, that normative evolution. Major national developments on LGBQTI human rights can provide a significant input into regional and international systems but they are not the subject of this article. 


\section{The United Nations System}

\section{The United Nations}

The United Nations (UN) is a global international organisation. Only States can be members. As of October 2018, it was composed of 193 member States. The principles and purposes of the UN are set out in the purposes and principles set out in the UN Charter (1945) (Higgins, 2017). One of the purposes of the Charter is 'To achieve international co-operation in solving international problems of an economic, social, cultural, or humanitarian character, and in promoting and encouraging respect for human rights and for fundamental freedoms for all without distinction as to race, sex, language, or religion' (Article 1(3)). Under Article 55, 'With a view to the creation of conditions of stability and well-being which are necessary for peaceful and friendly relations among nations based on respect for the principle of equal rights and self-determination of peoples, the United Nations shall promote... universal respect for, and observance of, human rights and fundamental freedoms for all without distinction as to race, sex, language, or religion.' All Members pledge themselves to take joint and separate action in co-operation with the Organization for the achievement of the purposes set forth in Article 55 (Article 56). Although Article 2(7) of the Charter stated that nothing contained in it 'shall authorize the United Nations to intervene in matters which are essentially within the domestic jurisdiction of any state', in practice the Charter has been interpreted as establishing a very wide competence on human rights for the UN. Article 2(7) has largely been interpreted out of existence (Higgins, 2017: 331-7).

The UN system is principally composed of 'Charter bodies', that is, those established under the UN Charter, and 'Treaty bodies' composed of independent experts, which are established under a series of major human rights treaties, but which operate under the auspices of the UN (http://www.un.org/en/sections/what-we-do/protect-humanrights/index.html). The 'principal organs' of the UN are the Economic and Social Council, 
the General Assembly, the Security Council, the Trusteeship Council, and the International Court of justice. The major forums within the UN system where general human rights issues are discussed are the General Assembly, particularly its Third Committee (Social, Cultural and Humanitarian) and Sixth Committee (Legal), the Human Rights Council, the subsidiary bodies and organs established by the Human Rights Council, and within the Treaty Body system.

In addition, the Charter permitted certain organs to create subsidiary organs and bodies, many of which have competence in human rights. So too do many of the $17 \mathrm{UN}$ 'Specialized Agencies' which deal with economic, social, cultural, educational, health and related fields. Significant attempts have been made to mainstream human rights across the UN system, at least at the policy level. The Office of the High Commissioner for Human Rights (OHCHR) has a major responsibility to ensure the mainstreaming of human rights.

The complex and evolving 'UN system' thus provides a multiplicity of forums for dialogue between member states, international organizations and non-governmental organizations (NGO's). Some of these forums are explicitly designated as human rights forums while other have mandates relating to wider security, economic, social, humanitarian and legal issues. Human rights has become something of a meta-language. Thus, there are a range of UN or UN related forums and mechanisms under which LGBTQI human rights can be, and have been, considered.

Oscar Wilde wrote that, 'There is only one thing in the world worse than being talked about, and that is not being talked about (Wilde, 1890). Not being talked about was very much the experience of LGBQTI rights/ sexual orientation and gender identity issues (SOGI) 
(an abbreviation I use for convenience to reflect its widespread use in UN forums even when not specifically consider any gender identity issues) at the United Nations (UN) (McGill, 2014). Certainly by comparison with some of the regional organizations such as the EU (Swiebel, 2009), progress at the UN has been slower and more contested (Parker, Petchesky and Sember, 2007; Corrêa, Petchesky and Parker, 2008; Sheill, 2009; Karsay, 2014). Only in the 1990s was significant attention directed to sexual orientation issues (Heinze, 1995 and 2001; Wintemute 1995). Since then there have been, and continue to be, battles fought by states, non-governmental organizations (NGOs) and international NGO's (INGOs) concerned with LGBQTI rights to be accredited with consultative status to the UN and then to get LGBQTI issues framed in human rights terms and onto the agendas of UN committees and its 17 Specialized Agencies (Sanders, 1996; Swiebel, 2009). Only in the 1990 did Amnesty International and Human Rights Watch, the so-called gatekeepers of the NGO movement, accept LGBQTI related rights as part of their mandates (Amnesty International 1994; Linde, 2017). 2006 saw the adoption by a distinguished group of international human rights experts of the Yogyakarta Principles on the Application of International Human Rights Law in relation to Sexual Orientation and Gender Identity. An updated version was published in 2017 (www.yogyakartaprinciples.org/principles_en.htm). This document sought to apply existing international human rights law standards to address the situation of LGBT people, and issues of intersexuality (O'Flaherty and Fisher, 2008; Waites, 2009; Thoreson, 2009). The OHCHR, UN Special Procedures, UN human rights treaty bodies and the Council of Europe Commissioner for Human Rights have referenced the Yogyakarta Principles. Again though there has been opposition from some states to their being referenced in UN Reports (Otto, 2013). The implicit assumption has been that identification of sexual orientation issues in an 'international human rights' discourse within existing international mechanisms and 
institutions was a necessary, if not a sufficient, condition for having a positive impact on the lives of those concerned.

\section{UN General Assembly}

The GA is a political body on which each of the 193 members of the UN are represented. Under the United Nations Charter (1945) it has wide-ranging competences (Higgins et al, 2017). Despite the prohibition in Article 2(7) of the Charter on the UN intervening in matters which are 'essentially within the domestic jurisdiction' of member states, a highly complex and intrusive international human rights system has been developed. However, although the scope of international human rights has developed dramatically since 1945 , the foundational issue of whether LGBTQI issues fall within recognised international human rights has been the subject of major political contestation (Roseman and Miller, 2011; Chase, 2016). A Pew survey in 2013, reported in 'The Global Divide on Homosexuality', found huge variance between states and between different regions on the broader question of whether homosexuality should be accepted or rejected by society (See www.pewglobal.org [last accessed 4 March 2019). Even within the same state attitudes towards sexual orientation discrimination are often very diverse. The strong public opposition in many states is particularly linked to notions of tradition, culture, the degree of religiosity and the effects of relative poverty. Unsurprisingly, those national and regional differences are reflected at the UN. The UN thus represents a major political site for contestation over LGBQTI rights (Mulé, Khan and McKenzie 2017; Vance et al 2018) in the same way it has been for other 'new' human rights (Bob, 2009). The political discourse is creatively played out both by states which support them and states, including the Holy See (which has status of permanent observer at the UN) (Beattie, 2014; Tomasi, 2018), which oppose them. Each side of the 
debate is supported and pressured by an increasing number of, and qualitatively better organized and financed, NGOs and INGOs (Thoreson, 2014). Individual human rights defenders have also gained greater national and international visibility (Mulé, 2018). Both sides have adopted multiple parallel strategies. The coalition and alliances on one side of the arguments seeks to undermine the unity and coherence of the coalition and alliances on the other. Religions that have divided on many other issues have been more united against LGBQTI rights. They have used their global networks and alliances aided by well financed religious NGOs (the so-called 'Religious Right') that can also operate regionally or globally. Each side engages in promotion or obstruction via procedural manoeuvres relating to agendas, discussions, and voting. So too with respect to substantive debates on policies, concepts, mandates and the use of language. The outcomes of these contestations are reflected in major UN political texts relating to, for example, population, sustainable development, and women's rights (Beattie, 2014). Greater acceptance of 'sexual rights', at least in the contexts of health, HIV and domestic violence, may gradually have become diplomatically tolerable. Less so references to 'sexual orientation' or 'gender identity' (Girard 2007; Waites 2009).

By 2008 a Joint Statement on the human rights of LGBT persons sent to the GA, which reaffirmed 'the principle of non-discrimination, which requires that human rights apply equally to every human being regardless of sexual orientation or gender identity', had the support of 66 states. The US originally opposed the Statement but changed its position in 2009. However, the Statement was met by a negative formal Response by 57 states. GA Resolutions are political statements. They are not legally binding as such but they can provide evidence of what States consider to be legally binding. Since 2003, GA resolutions on 'extrajudicial, summary or arbitrary executions' have made reference to international law obligations to investigate killings of persons 'because of their sexual orientation or gender 
identity'. However, a Brazilian proposal in the then UN Human Rights Commission to adopt a resolution specifically on sexual orientation was delayed in 2003 and then dropped in 2004 in the light of strong political opposition, led in part by the Holy See (Jordaan, 2016).

Given that the UN has a very wide competence and considers many politically controversial issues and situations, this level of existential norm contestation is relatively unusual (Altman and Symons (2016); McGoldrick 2016). However, the fact is that different states take diametrically opposite positions on the question of whether the rights LGBTQI persons are claiming are "existing" or "new" rights (Roseman and Miller 2011; Picq and Thiel 2015).

\section{UN Human Rights Council}

The UN Human Rights Council is a subsidiary body of the GA. It is the principal UN intergovernmental political body within the $\mathrm{UN}$ for the consideration of human rights issues (Freedman, 2013; Higgins, 2017; Alston, 2018). It is composed of 47 states, divided into 5 regional groups, and elected by the GA for 3-year terms. It replaced its predecessor, the Human Rights Commission, in 2006, in part because Commission's credibility had been undermined by allegations of political selectivity in its monitoring and criticism of the human rights performance of particular states. The Council meets three times a year, for a minimum of ten weeks. Since its establishment, the number of references to sexual orientation in reports to the Human Rights Council has steadily increased. There has also been an increase in the number of states who are willing to discuss human rights issues in terms of sexual orientation discrimination. In 2006, at the Human Rights Council, 54 states submitted a Joint Statement on human rights, sexual orientation and gender identity. By 2011 a similar Statement entitled 'Ending Acts of Violence and Related Human Rights Violations Based on 
Sexual Orientation and Gender Identity' was submitted by 85 states (available at: www.state.gov/r/pa/prs/ps/2011/03/158847.htm.). That Statement had support from every region of the world, including 21 signatories from the Western Hemisphere, 43 from Europe, 5 from Africa and 15 from the Asia/Pacific region. 94 Member states of the UN have sponsored a Statement in support of LGBT rights in either the GA, the Human Rights Commission/ Council, or in both.

\section{UN Human Rights Council Resolutions 17/19 (2011) and 27/32 (2014)}

In June 2011, the Human Rights Council adopted Resolution 17/19 on 'Human Rights, Sexual Orientation and Gender Identity'. This was the first specific UN resolution on sexual orientation and gender identity. The Resolution was controversial and was only narrowly passed, by 23 votes to 19, with three abstentions. Those in support were Argentina, Belgium, Brazil, Chile, Cuba, Ecuador, France, Guatemala, Hungary, Japan, Mauritius, Mexico, Norway, Poland, Republic of Korea, Slovakia, Spain, Switzerland, Thailand, Ukraine, UK, US, and Uruguay. South Africa was a notable co-sponsor of the Resolution even thought it was not a member of the Council. The Resolution expressed 'grave concern' at violence and discrimination against individuals based on their sexual orientation and gender identity. It also requested what became the first official UN report on the issue prepared by the Office of the UN High Commissioner for Human Rights (OHCHR) on 'Discriminatory Laws and Practices and Acts of Violence Against Individuals based on their Sexual Orientation and Gender Identity' (OHCHR, 2011). The Report's findings formed the basis of a Panel discussion that took place at the Human Rights Council in March 2012. Remarkably, the Panel discussion was the first time a UN intergovernmental body had held a formal debate on the subject. In 2012, the OHCHR published an extensive report setting out the set out the core 
obligations that states had towards LGBT persons, and described how UN had applied international law in this context (OHCHR, 2012).

However, there was significant political opposition to Resolution 17/19. The 19 states which opposed the Resolution were Angola, Bahrain, Bangladesh, Cameroon, Djibouti, Gabon, Ghana, Jordan, Malaysia, Maldives, Mauritania, Nigeria, Pakistan, Qatar, Republic of Moldova, Russian Federation, Saudi Arabia, Senegal and Uganda. Burkina Faso, China and Zambia abstained. Most of the 17 delegates of UN Member states in the Organisation of Islamic Cooperation (OIC), (which represents 57 countries in Africa, Asia and the Middle East) who were members of the Human Rights Council, walked out of the Human Rights Council in protest. Though it appeared only Muslim delegates walked out, there was reported to be widespread opposition to what is pejoratively described as the 'homosexual agenda' at the UN. Even within the states that took part in the Panel discussion, strong objections were expressed. The OIC is particularly significant in both the GA and the Human Rights Council because of its numerical size. Pakistan, speaking on behalf of the OIC, opposed the controversial notion of sexual orientation, which was vague and misleading, had no agreed definition and no legal foundation in international law. Licentious behaviour promoted under the concept of sexual orientation was against the fundamental teachings of various religions including Islam. Legitimizing homosexuality and other personal sexual behaviours in the name of sexual orientation was unacceptable to the OIC. Mauritania, speaking on behalf of the Arab Group, opposed any discussion of the subject of sexual orientation. Debate on the issue would lead to further discord among member states and undermine the Council's effective response to human rights issues. Attempts to impose the controversial topic of sexual orientation were aimed at creating new rights for specific cultural values, which would have negative effects on social structures. Senegal, on behalf of the majority of the member states of the African 
Group, reaffirmed the importance of respecting cultural and religious values when it came to dealing with human rights issues, and rejected any attempt to impose concepts or notions on certain behaviours, which did not fall into the internationally agreed set of human rights. Nigeria argued that other states were seeking to enforce their cultural values abroad. Of the African states that were on the Human Rights Council in 2011 only South Africa (significantly a co-sponsor of the Resolution) and Mauritius voted for the Resolution. Since the 2011 Resolution, the African Group at the UN has pressured South Africa into not spearheading SOGI issues.

Despite the strength of the opposition, like-minded states in the UN LGBT Core Group continued to work strategically and as norm entrepreneurs (Baisley, 2016) to promote the wider recognition of sexual orientation discrimination as part of LGBT rights. The Core Group is a cross-regional group that includes 17 states, the European Union, as well as the OHCHR, Human Rights Watch and the International Gay and Lesbian Human Rights Commission. No Human Rights Council resolution was obtained in 2013 because of the opposition of some states. However, in 2014 the Human Rights Council adopted Resolution 27/32 on Human Rights, Sexual Orientation and Gender Identity (26 September 2014, A/HRC/RES/27/32.) by a vote of 25 in favour, 14 against and seven abstentions. The Resolution was led by a group of Latin American states (Brazil, Chile, Colombia and Uruguay) and adopted with the support of all five UN regional groups (though strong criticism within the African Group had dissuaded South African support). The Resolution requested the High Commissioner to update the 2011 Report on Discriminatory laws and practices and acts of violence against individuals based on their sexual orientation and gender identity, 'with a view to sharing good practices and ways to overcome violence and discrimination, in application of existing international human rights law and standards'. 


\section{UN Human Rights Council - Universal Periodic Review}

As noted, the Human Rights Council replaced the Human Rights Commission. One of the major reasons was because it was perceived that the Commission had been unduly selective in its monitoring and criticism of the human rights performance of particular states. An important aspect of the reform was the introduction of the system of Universal Periodic Review (UPR) under which the human rights performance of all member states would take place over some 4-5 years (Human Rights Council Resolution 5/1, 'Institution-Building of the UN Human Rights Council', 18 June 2007.) The bases for UPR are the UN Charter, the Universal Declaration of Human Rights (1948), the human rights instruments to which a state is party, and voluntary pledges and commitments made by states. It does not involve new substantive human rights obligations. The UPR processes are more in the nature of dialogic and advisory systems and do not result in a legally binding outcome. The procedures have evolved since its introduction and have offered an important space within the UN system for systematic discussion of sexual orientation issues and for civil society engagement (Karsay, 2014; Charlesworth and Larking, 2015). Civil society organizations (CSOs), including NGOs, can submit information as stakeholders. SOGI issues have frequently been raised with states during the UPR process. This is not surprising because states can choose which issues to comment on during the interactive dialogue. Recommendations on SOGI issues have been made since the first session (2008) of the first UPR cycle (2008-2011). The number of SOGI recommendations has increased dramatically, doubling in the second cycle (2012-16). As of March 2019, 1,718 recommendations had been made on SOGI issues in all UPR cycles (the third cycle runs from 2017-21). 56 states had raised such issues and 173 states had received such recommendations (UPR Info's Database of UPR recommendations and voluntary pledges, available at: www.uprinfo.org/database/statistics/index_issues.php?fk_issue $1 / 447 \&$ cycle $1 / 4$ [last accessed 4 March 
2019]). The recommendations range from the specific, repeal the provisions of the penal code which criminalise sexual relations between consenting adults of the same sex, to the general, to take the necessary measures to combat discrimination based on sexual orientation More revealing can be the responses to recommendations. 635 (37\%) had been supported, that is, accepted, while $1082(63 \%)$ had been noted (which is effectively a rejection as, since 2014, there is now no option to reject). The State has the primary responsibility to implement the recommendations that it has supported. As the UPR process has worked through all UN members, many states have openly rejected recommendations to decriminalize homosexuality and legalize same-sex marriage or adoption. However, some states, for example, Nauru, have responded more positively by agreeing to decriminalize or review criminalization.

Recommendations to investigate allegations of violence against LGBT persons more effectively have received a more favourable response. More than 100 states from all regions have committed to address violence and discrimination on the basis of SOGI. The breadth of the UPR process can allow for degrees of subtlety. Thus some States which note (reject) all recommendations calling for general non-discrimination and 'decriminalization' may accept highly targeted specific recommendations on aspects of sexual orientation discrimination, for example, concerning police violence, education and impartial investigations.

\section{UN Special Procedures}

The UN Special Procedures of the Human Rights Council are prominent, independent experts working on a voluntary basis, who examine, monitor, publicly report and provide advice on human rights from a thematic or country-specific perspective. Special procedures are individual independent human rights experts, or groups of such experts, who report and advise on human rights issues. They are called by many names, including Special Rapporteurs, Special Representatives, Working Groups, and Independent 
Experts. As of 2018, there were 56 such Special Procedures. 44 were thematic and 12 country specific). They are dialogic and advisory systems (Nolan et al, 2017). Though interpretations offered may be persuasive and authoritative, the work of the Special Procedures does not result in legally binding outcomes (Limon and Piccone 2014). Sexual orientation discrimination issues have increasingly been mainstreamed and many of the UN Special Procedure mandate holders have raised these issues within the context of their respective mandates. The number of references to sexual orientation and LGBT persons in their reports to the Human Rights Council and in communications to states by Special Procedures is steadily increasing, although some states have objected to this practice because they do not accept that sexual orientation is a properly distinct category of human rights law.

The Appointment of an Independent UN Expert on the protection against violence and discrimination based on sexual orientation and gender identity

There are some 44 thematic Special Procedures. However, it is notable that, despite the increasing prominence of the issue, until 2016there had never been a proposal for a UN Special Procedure on the theme of discrimination based on sexual orientation. On 30 June 2016, the Human Rights Council adopted Resolution 32/2 entitled 'Protection against Violence and Discrimination based on Sexual Orientation and Gender Identity' (A/HRC/RES/32/2). The major political and institutional development was the creation by the Human Rights Council of a UN Independent Expert on the protection against violence and discrimination based on sexual orientation and gender identity. The Resolution was adopted by 23 votes to 18 with six abstentions and a number of amendments to it were adopted against the wishes of the sponsors. The successful amendments inserted references to respecting 'regional, cultural and religious value systems', 'domestic debates', 'sovereign 
priorities', expressing concern around 'concepts pertaining to social matters including private individual conduct', stressed the need to 'maintain joint ownership of the international human rights agenda and to consider human rights in an 'objective and non confrontational manner' and deplored the use of external pressure and coercive measures against States, particularly developing countries. There was a bitter debate in the Council in which arguments of equality and universality were counter-posed to allegations of the imposition of Western perceptions of human rights, and failure to recognize religious, cultural and social differences. The Russian Federation, Saudi Arabia and Indonesia immediately stated that they would not cooperate with the Independent Expert.

As noted, member states on the Council were deeply split over the appointment. For the first time ever, there was a series of votes in the General Assembly in an attempt to delay or reverse it, partly because sexual orientation and gender identity had no clear basis in international human rights law (ARC International, 2016; Outright et al, 2017). The proposal survived but the voting was very close. In broad terms there was strong support from Latin America, Europe and North America and strong opposition from the African bloc (though South Africa was strongly supportive partly based on its post-apartheid constitutional values) and the OIC.

The first 'Independent Expert', Vitit Muntarbhorn (Thailand), was appointed in September 2016. He was succeeded by Victor Madrigal-Borloz (Costa Rica) in January 2018. The Expert's mandate includes implementing international instruments, with identification of good practices and gaps; promoting awareness of the violence and discrimination issue, and linking with root causes; engaging, consulting, and cooperating with states and other stakeholders; identifying multiple, intersecting, and aggravated forms of violence and discrimination; and supporting international cooperation and related services to assist national efforts (https://www.ohchr.org/EN/Issues/SexualOrientationGender/Pages/Index.aspx). In the 
discharge of the mandate, the Independent Expert transmits urgent appeals and letters of allegation to states with regard to cases of violence and discrimination against persons on the basis of their sexual orientation or gender identity, undertakes fact-finding country visits and submits annual reports to the Human Rights Council, and GA, on the activities, trends and methods of work (Independent Expert on sexual orientation and gender identity, 2018).

\section{UN Treaty Bodies}

The Treaty bodies are composed of independent experts. So they are not directly controlled by States and political divisions are less evident. However, none of the nine major UN human rights treaties contain any express reference to sexual orientation. It is through the mechanism of treaty interpretation by the treaty bodies that some of the strongest protections against discrimination on the basis of sexual orientation have been achieved at the UN. Some of the earliest and leading treaty body jurisprudence was developed by the Human Rights Committee under the International Covenant on Civil and Political Rights (1966), which has 171 states parties. In a landmark decision in Toonen $v$ Australia in 1994 the HRC interpreted 'sex' in Articles 2(1) and 26 of the ICCPR as covering 'sexual orientation' and thus states parties are obliged to protect individuals from discrimination on the basis of their SOGI (though there are risks to problematizing SOGI discrimination as 'sex' discrimination (Lau, 2018). All of the UN human rights treaty bodies now raise sexual orientation issues as they relate to their respective mandates on a regular basis. The Committee against Torture, the Committee on the Rights of the Child, the Committee on the Elimination of Discrimination against Women and the Committee on Economic, Social and Cultural Rights, have all adopted General Comments which have included reference to sexual orientation. A good example is the latter's General Comment on the 'right to sexual and reproductive health' 
(2016) in sections dealing with interdependence with other human rights, the accessibility of information, non-discrimination and equality, intersectionality and multiple discrimination.

\section{The UN as an international organization}

In terms of its own practice as an international organization, the UN's employment practices are supportive of LGBQTI persons. In 2014 the UN, which has some 43,000 staff, announced that it would globally extend its employee benefits to workers in same-sex marriages or other unions in jurisdictions where they are legal.

UN agencies and organs such as UN Development Programme, UNESCO, International Labour Organization, World Health Organization, UN Population Fund, UNICEF and UNAIDS have integrated issues of sexual orientation and gender identity into their work. This is evidenced in a range of statements, reports and guidelines by those organizations. For example, the UN High Commissioner for Refugees (UNHCR) published 'Guidelines on International Protection No 9: Claims to Refugee Status based on Sexual Orientation and/or Gender Identity within the context of Article 1A(2) of the 1951 Convention and/or its 1967 Protocol relating to the Status of Refugees'. In September 2015, in an unprecedented joint initiative, $12 \mathrm{UN}$ agencies issued a joint call to action on ending violence and discrimination against LGBT and intersex adults, adolescents and children.

\section{Politics, Critique and Strategies}

The anti-colonial critique and the Protection of Culture, Traditional Values and the Family 
More than 3 billion people, almost half of the world population, live in the 72 countries in which law or other measures criminalizes on the basis of sexual orientation (Independent Expert on sexual orientation and gender identity, 2018). Violence and discrimination based on SOGI exist in all corners of the world (Carroll and Mendos, 2017). As noted, some African and Asian political and religious leaders have argued that gay rights and homosexual identities are against their national traditions, as well as their cultural and religious value systems. They also argue that they have a sovereign right to reject what is seen as an imperialist or postcolonial imposition of a particular human rights agenda by mainly Western states (Wilets, 2011), which have sought to influence national sentiment via aid and trade conditionality (Baisley, 2015). They resent the hypocrisy that although the United Kingdom presents itself as a global leader in LGBTQI rights, it was under British colonial rule that homosexual acts were first criminalized in many of its colonial territories around the world (Richards, 2013). Many of those colonial laws remain in force, for example in Bangladesh, Brunei, India, Malaysia, Myanmar, Pakistan, Singapore, and Sri Lanka (Lennox and Waites 2013; Nicol, N. (2018). The argument is that acceptance of homosexuality is a cultural import from the West (a claim that has also been used to oppose the equality of women). This argument disregards the fact that culture and tradition are neither static nor monolithic. Nonheteronormative sexual orientations and gender identities have existed in all world regions, including Africa. Some Asian countries, such as Malaysia and the Maldives have made similar claims. Yet even in regions that are broadly negative on LGBTI rights, there are strong pockets of resistance, especially in Nepal, South Africa, Japan, and Taiwan. These arguments based on culture and tradition are not confined to Africa and Asia' they are also invoked in Central and Eastern Europe and parts of the Russian Federation (Trappolin et al. 2012). It is notable that both sides of the culture argument have utilized the same paragraph of the 1993 Vienna Declaration and Programme of Action of the World Conference on 
Human Rights (UN Doc. A/CONF.157/23, para 5, 25 June 1993) to support their understanding of human rights law. One side emphasizes the "various historical, cultural, and religious backgrounds" that must be borne in mind, while the other points to the "duty of States, regardless of their political, economic and cultural systems, to promote and protect all human rights and fundamental freedoms." The debate on LGBQTI rights is increasingly being played out by reference to resolutions on 'traditional values', with which human rights should be consistent (Wilkinson, 2014), and the 'Protection of the Family', understood as the nuclear, heterosexual 'family' and certainly not as multiple forms or varieties of 'families' (Buss and Herman 2003).

\section{Strategies for Managing the Differences on LGBQTI Human Rights}

It is simplistic to present the situation in states and regions as totally good in some and totally bad in others. Thinking in terms of regional blocks opposed to a norm on sexual orientation discrimination is also misleading. For example, it is clear both in Africa and in the ASEAN region that state practice is mixed and in a state of flux. Similarly, discussion in terms of regional or traditional 'values' or a singular idea of a 'family' belies the historical and social complexity of societies and communities in all regions of the world. As noted, in the UN Human Rights Council tendencies towards politicization along regional lines have been enhanced in relation to SOGI issues with voting patterns exposing major divisions. Repeating the resolutions just re-emphasizes the differences. So too when differences on sexual orientation issues impact on other resolutions on the protection of the family or traditional values. Diplomatic skills and cultural sensitivity suggest a need to focus on building cross-regional initiatives to curb the impression that sexual orientation rights is a 'Western' conspiracy against non-Western states. To some extent this is already happening in the Human Rights Council as resolutions on sexual orientation are led by a group of South 
American states. If the EU as a block seeks to advance sexual orientation issues in resolutions, it will meet resistance.

By promoting a dialogic approach, the UPR process arguably offers an alternative to a confrontational and antagonistic process of attempting to enforce politically and legally controversial human rights norms. In terms of substantive reform on SOGI issues, decriminalization can be viewed as a process towards a goal of non-discrimination on grounds of sexual orientation that is to be positively encouraged rather than an absolute indicator. From a practical perspective, achieving moratoriums (such as that in Malawi since 2012), non-enforcement of criminal laws, restricting the scope of applicable offences and educating the public are all elements of the process towards decriminalization. Similarly, some states have been more willing to respond more positively in terms of acting against violence based on sexual orientation and police violence, education and impartial investigations. Bringing in aspects of public health, as some of the UN treaty bodies have done, may be a good strategic move. Even if some states have been opposed to considering sexual orientation issues in these terms, in the long term the impact of the health issues on the rest of the population may force them to do so. For example, one argument is that decriminalization of homosexuality would decrease the propagation of HIV/AIDS.

There may also be traction in presenting the case that protecting LGBT rights is important to poverty reduction and that violations of human rights are likely to have a harmful effect on a state's economy and development. This has presented challenges for religiously based development organizations (Paine, 2018). However, the risks of using aid as a human rights strategy on culturally sensitive issues are well known. Aid conditionality can undermine and harm local movements that are working hard to improve understandings of sexual orientation and gender identity in specific local contexts. 
Finally, the then UN Secretary-General Ban Ki-moon in 2010 and the successive UN High Commissioners for Human Rights, starting with Navi Pillay, have stated repeatedly that there was an urgent need to challenge homophobia at its roots - through public education, training and information on LGBT issues. However, some states still engage in negationism. They deny that SOGI issues exits and therefore do not collect the date necessary to provide evidenced-based political and policy responses (Lee and Ostergard, (2017).

\section{Concluding Comments}

The strategic and policy responses to the issue of LGBQTI human rights at the UN have been complex and contested. Time, aided by the tolerance of younger persons on the issue, and the ubiquitous character of the internet and social media, may bring greater understanding and acceptance as they have with other grounds of non-discrimination such as race, sex, and more recently disability. In 2017, UN Free \& Equal, the UN's global campaign against homophobia and transphobia reached 2.4 billion social media feeds around the world and generated a stream of widely shared materials - including powerful videos, impactful graphics and plain-language fact sheets. Several campaign videos - including a popular Bollywood-themed clip "The Welcome" - (https://www.unfe.org/the-welcome-new/) rank among the most watched videos ever produced by the UN. National UN Free \& Equal campaigns and events have been organized in almost 30 countries, with visible support from UN, political, community and religious leaders and from celebrities in all regions of the world.. However, further progress on LGBQTI human rights is not inevitable. The divisions are complex and deep rooted. The complexity is evident at the regional level. In very broad terms, Europe (in the very widest sense) and the Americas are far in advance of the UN. In November 2013, the Inter-American Commission on Human Rights became the world's first intergovernmental human rights body to establish a Rapporteur on the Rights of Lesbian, 
Gay, Bisexual, Trans and Intersex Persons. By contrast, in broad regional terms, LGBT rights in Africa and Asia are greatly underdeveloped. However, the political reality is much more nuanced. Regions and States are complex and contain a range of institutional actors. It is not necessarily the case that the views of States in international or regional forums reflect all of the major institutional actors within those States or public opinion within those States. However, it remains the fact that while the former UN Secretary-General Ban Ki-moon considered that discrimination on grounds of sexual orientation was 'one of the great, neglected human rights challenges of our time', many States and their populations clearly do not. Even when there is a greater degree of acceptance of the problems, the issue is not seen a priority one.

\section{Future Research}

The 'Politics' of LGBQTI Human Rights in the UN System is conducted at multiple levels and in multiple forums. Highly technical UN resolutions contain hidden messages and symbolisms that only insiders understand. Future research will focus on which levels and forums offer the greatest probability of success and which contain hidden risks? Which States, groups of States or regions are best to lead the LGBT agenda? How and at what levels can the effectiveness of LGBT NGO's in norm development and norm receptivity be assessed? ,There is also the issue of the relationships between international, regional and domestic levels. Domestic jurisprudence may carry a greater domestic legitimacy and authority than international jurisprudence. Similarly, regional jurisprudence may carry a greater regional legitimacy and authority than international jurisprudence. Research needs to focus on whether decriminalization of same sex sexual activities require different strategies and stages depending on the legal system, degrees of entrenchment and degree of constitutionality, and receptivity to international or domestic human rights norms in any 
particular country (McGoldrick, 2019). Achieving moratoriums, non-enforcement of criminal laws, restricting the scope of applicable offences and educating the public are all elements of the process towards decriminalization that need to be studied. There also needs to be much more refined analysis of the economic issues - growing 'pink economy', the economic consequences of not addressing LGBT health issues, and the relationship between LGBT rights and sustainable economic development,. In 2017, the UN Human Rights Office developed a global Standards of Conduct for Business (https://www.unfe.org/wpcontent/uploads/2017/09/UN-Standards-of-Conduct.pdf) intended to support the private sector in fostering diversity and promoting a culture of respect and equality. More empirical evidence needs to be undertaken to demonstrate that doing so brings economic benefits, by helping attract and retain talent, improving decisions and building loyalty with customers and investors alike. In May 2018, a group of United Nations and international human rights experts expressed concern that LGBT people are, in the context of sustainable development, being effectively left behind. Actions to address such systematic exclusion rely among other, on the availability of data and on ensuring that disaggregated data collection and management are implemented in strict compliance with human rights standards (International Group of Experts, 2018). A 2019 Report of the Independent Expert on protection against violence and discrimination based on sexual orientation and gender identity to the Human Rights Council discusses the types of data relevant to assess violence and discrimination based on sexual orientation and gender identity; map what data are already being collected, by whom, and for what purpose; highlight key human rights safeguards that must be taken into consideration when collecting and using data; and formulate recommendations to States and other relevant stakeholders. 


\section{References}

Amnesty International. (1994). Breaking the Silence. New York: Amnesty International.

ARC International. (2016). Appointing an Independent Expert on Sexual Orientation and Gender identity: An Analysis of Process, Results and Implications. http://arcinternational.net/wp-content/uploads/2016/08/HRC32-final-report-EN.pdf.

Alston, P., and Megret, F. (eds) (2018). The UN and Human Rights. 2nd edn. Oxford: Oxford University Press.

Altman, D., and Symons, J. (2016). Queer Wars. Cambridge: Polity Press.

Ayoub, PM. (2016). When States Come Out - Europe's Sexual Minorities and the Politics of Visibility. Cambridge: Cambridge University Press.

Baisley, E. (2015) "Framing the Ghanaian LGBT Rights Debate: Competing Decolonisation and Human Rights Frames.” Canadian Journal of African Studies 492): 383-402.

Baisley, E. (2016). "Reaching the Tipping Point? Emerging International Human Rights Norms Pertaining to Sexual Orientation and Gender Identity." Human Rights Quarterly 38:134-63. 
Beattie, T. (2014). "Whose Rights, Which Rights? - The United Nations, the Vatican, Gender and Sexual and Reproductive Rights." Heythop Journal 55(6): 1080-1090.

Bob, C. (2009). The International Struggle for New Human Rights. Philadelphia: University of Philadelphia Press.

Buss, D., and Herman, D. (2003). Globalizing Family Values: The Christian Right in International Politics Minneapolis, MN: University of Minnesota Press.

Carroll, A., and Mendos, L.R. (2017). State-Sponsored Homophobia 2017: A World Survey of Sexual Orientation Laws: Criminalisation, Protection and Recognition. Geneva: International Lesbian and Gay Association.

Charlesworth, H., and Larking, E. (eds). (2015) Human Rights and the Universal Periodic Review: Rituals and Ritualism. Cambridge: Cambridge University Press.

Chase, A.T. (2016). 'Human Rights Contestations: Sexual Orientation and Gender Identity', International Journal of Human Rights 20(6): 703-23.

Corrêa, S., Petchesky, R.P., and Parker, R. (2008). "Inventing and Contesting Sexual Rights Within the UN.” in Corrêa, S., Petchesky, R.P., and Parker, R., Sexuality, Health and Human Rights (pp. 164-74). London: Routledge.

Freedman, R. (2013). The UN Human Rights Council: a critique and early assessment. London: Routledge. 
Girard, F. (2007) 'Negotiating Sexual Rights and Sexual Orientation at the UN' in Parker, R., Petchesky, R. and Sember, S. (eds), Sex Politics: Reports from the Frontlines (pp. 311-58), available at: http://www.sxpolitics.org/frontlines/book/pdf/capitulo9_united_nations.pdf [last accessed 4 March 2019].

Heinze, E. (1995) Sexual Orientation: A Human Right. (Oxford: Oxford University Press))

Heinze, E. (2001). "Sexual Orientation and International Law: A Study in the Manufacture of Cross-Cultural 'Sensitivity'.’ Michigan Journal of International Law 22: 283-309.

Higgins, R. et al, (2017). Oppenheim's International Law: United Nations. (Oxford: Oxford University Press).

Independent Expert on sexual orientation and gender identity (2018). "Report of the Independent Expert on protection against violence and discrimination based on sexual orientation and gender identity". UN Doc A/HRC/38/43. Geneva: UN.

International Group of Human Rights Experts, 2018, Leave no LGBT person behind, 17 May 2018, available at https://www.ohchr.org/en/NewsEvents/Pages/DisplayNews.aspx?NewsID=23092\&La $\operatorname{ngID}=\mathrm{E}$.

Jordaan, E. (2016). “The Challenge of Adopting Sexual Orientation Resolutions at the UN Human Rights Council.” Journal of Human Rights Practice 8: 298-310. 
Johnson, P. (2013). Homosexuality and the European Court of Human Rights. (Routledge: Abingdon).

Karsay et al. (2014). "How far has SOGII advocacy come at the UN and where is it heading?", September 2014, available at: arc-international.net/wp-content/up loads/2013/09/How-far-has-SOGII-for-web.pdf [last accessed 4 March 2019].

Lau, H. (2018) “Sexual Orientation and Gender Identity Discrimination.” (2018)

Comparative Discrimination Law 2: 1-52.

Lee, C., and Ostergard, R.L. (2017). "Measuring Discrimination against LGBTQ People: A Cross-National Analysis.” Human Rights Quarterly 39: 37-72.

Lennox, C., and Waites, M. eds. (2013) Human Rights, Sexual Orientation and Gender Identity in the Commonwealth: Struggles for Decriminalisation and Change. London: Institute of Commonwealth Studies.

Limon, M. and Piccone, T. (2014). U.N. Human Rights Experts: Determinants of Influence, Versoix: Universal Rights Group. available at www.brookings.edu/research/u-nhuman-rights-experts-determinants-of-influence/ [last accessed 4 March 2019].

Linde, R. (2017). "Gatekeeper Persuasion and Issue Adoption: Amnesty International and the Transnational LGBTQ network.” Journal of Human Rights 17: 245-64

McGill, J. (2014) "SOGI . . . So What? Sexual Orientation, Gender Identity and Human Rights Discourse at the United Nations." Canadian Journal of Human Rights 3: 1-38. 
McGoldrick, D. (2016). “The Development and Status of Sexual Orientation Discrimination under International Human Rights Law.” Human Rights Law Review 16: 613-68.

McGoldrick, D. (2019). “Challenging the Constitutionality of Restrictions on Same-Sex Sexual Relations: Lessons from India.” Human Rights Law Review 19: 173-185.

McIntosh Sundstrom, L. Sperling, V., and Sayoglu, M. Courting Justice - Russia, Turkey, and the European Court of Human Rights. Oxford: Oxford University Press.

Mulé, N.J., Khan, M., and McKenzie, C. (2017). "The growing presence of LGBTQIs at the UN: Arguments and counter-arguments.” International Social Work 60: 1-13.

Mulé, N.J. (2018). "LGBTQI-identified human rights defenders: courage in the face of adversity at the United Nations". Gender and Development 26: 89-101.

Nicol, N. (2018). Envisioning Global LGBT Human Rights: (Neo)colonialism, Neoliberalism, Resistance and Hope. London: Institute of Commonwealth Studies.

Nolan, A., Freedman, R. and Murphy, T. (eds.). (2017) The United Nations Special Procedures System. (Leiden: Brill).

Office of the UN High Commissioner for Human Rights (OHCHR). (2011). 'Discriminatory Laws and Practices and Acts of Violence Against Individuals based on their Sexual Orientation and Gender Identity' (UN Doc A/HRC/19/41). Geneva: United Nations. 
Office of the High Commissioner for Human Rights (OHCHR). (2012). Born Free and Equal: Sexual Orientation and Gender Identity in International Human Rights Law. Geneva: United Nations.

O'Flaherty, M. and Fisher, J. (2008) “Sexual Orientation, Gender Identity and International Human Rights Law: Contextualising the Yogyakarta Principles." Human Rights Law Review 8: 207-248.

OutRight, ISHR, ILGA, and ARC International. (2017), Defending the Independent Expert on Protection Against Violence and Discrimination Based on Sexual Orientation and Gender Identity, available at https://ilga.org/downloads/Defending_IE_SOGI_UNGA71.pdf.

Otto, D. (2013). “Transnational Homo-Assemblages: Reading “Gender” in Counter-terrorism Discourses.” Jindal Global Law Review 4: 79-97.

Paine, C. (2018) “Christian Aid and LGBTI rights: breaking the silence." Gender and Development 26 155-72.

Parker, R., Petchesky, R. and Sember, S. (eds), Sex Politics: Reports from the Frontlines (pp. 311-58), available at: http://www.sxpolitics.org/frontlines/book/pdf/capitulo9_united_nations.pdf [last accessed 4 March 2019] 
Pew Research Center. (2013) “The Global Divide on Homosexuality”.

http://www.pewglobal.org/2013/06/04/the-global-divide-on-homosexuality/.

Picq, M.L. and Thiel, M. eds. (2015) Sexualities in World Politics: How LGBTQ Claims Shape International Relations. London: Routledge.

Roseman, M. and Miller, A.M. (2011) "Normalizing Sex and Its Discontents: Establishing Sexual Rights in International Law." Harvard Journal of Law and Gender 34: 313375.

Richards, D.A.J. (2013). The Rise of Gay Rights and the Fall of the British Empire (Cambridge: Cambridge University Press).

Sanders, D. (1996). "Getting Lesbian and Gay Issues on the International Human Rights Agenda." Human Rights Quarterly 18: 67-106.

Sheill, K. (2009), "Human Rights, Sexual Orientation, and Gender Identity at the UN General Assembly.” Journal of Human Rights Practice 1: 315-19.

State Obligations Concerning Change of Name, Gender Identity, and Rights Derived from a Relationship Between Same-Sex Couples, Inter-American Court of Human Rights (Advisory Opinion, 2018, Series A, No 24/17, available at http://www.corteidh.or.cr/docs/opiniones/seriea_24_esp.pdf. 
Swiebel, J. (2009). "Lesbian, Gay, Bisexual and Transgender Human Rights: The Search for an International Strategy." Contemporary Politics 15: 19-35.

Thoreson, RR. (2009) “Queering Human Rights: The Yogyakarta Principles and the Norm That Dare Not Speak Its Name.” Journal of Human Rights 8(4):323-339

Thoreson, R.R. (2014) Transnational LGBT Activism. Minneapolis: University of Minnesota Press.

Tomasi, S.M. (2017). The Vatican in the Family of Nations: Diplomatic Actions of the Holy See at the UN and other International Organizations in Geneva Cambridge; Cambridge University Press.

Trappolin, L. Gasparini, A., and Wintemute, R. eds. (2012) Confronting Homophobia in Europe: Social and Legal Perspectives. Oxford: Hart.

UN High Commissioner for Refugees (2015). Protecting Persons With Diverse Sexual Orientations And Gender Identities. (Geneva: UN). http://www.refworld.org/docid/566140454.html [accessed 15 October 2018]

Vance et al (2018). "The Rise of SOGI: Human Rights for LGBT People at the United Nations", in Nicol, N. et al (eds) Envisioning: Global LGBT Human Rights. London: Institute of Commonwealth Studies/Human Rights Consortium. 
Waites, M. (2009). “Critique of 'Sexual Orientation' and 'Gender Identity' in Human Rights Discourse: Global Queer Politics beyond the Yogyakarta Principles”, Journal of Contemporary Politics 15: 137-56.

Wilets, J.D. (2011). "From Divergence to Convergence? A Comparative and International Law Analysis of LGBTI Rights in the Context of Race and Post-colonialism.” Duke Journal of Comparative and International Law 21: 631-686.

Wilkinson, C. (2014). "Putting "Traditional Values" into Practice: The Rise and Contestation of Anti-Homopropaganda Laws in Russia.” Journal of Human Rights 13: 363-79.

Wintemute, R. (1995) Sexual Orientation and Human Rights. Oxford: Oxford University Press.

Wilde, O. (1890, 1992). The Picture of Dorian Gray. London: Wordsworth Classics, original 1890).

Nicol, N. (2018). Envisioning Global LGBT Human Rights: (Neo)colonialism, Neoliberalism, Resistance and Hope. London: Institute of Commonwealth Studies. 